\title{
Analyzing community resilience as an emergent property of dynamic social- ecological systems
}

\author{
Lucy Faulkner $^{1}$, Katrina Brown ${ }^{1}$ and Tara Quinn ${ }^{1}$
}

\begin{abstract}
Community resilience is widely promoted so that communities can respond positively to a range of risks, including shocks, extreme events, and other changes. Although much research has identified characteristics or capacities that confer resilience, resilience is more than simply the sum of these. Resilience is an emergent property - the capacities are linked and act together. We present an empirical analysis of five different capacities and assess how interactions between them confer resilience in two coastal communities in Cornwall, UK. These capacities are place attachment, leadership, community cohesion and efficacy, community networks, and knowledge and learning. Based on a survey and focus group discussions, our results show that residents draw on these capacities in different combinations, enabling resilience in diverse ways. This provides a dynamic and socially nuanced perspective on community resilience as process, potentially informing theory and practice of conservation, disaster risk reduction, climate change adaptation, and community development.
\end{abstract}

Key Words: community cohesion; community efficacy; community networks; community resilience; Cornwall; emergent property; knowledge; leadership; learning; place attachment

\section{INTRODUCTION: A NEW LENS ON COMMUNITY RESILIENCE}

The resilience of a community influences its collective ability to respond to multiscalar environmental, political, and socioeconomic change (Maclean et al. 2014). Enhancing community resilience is seen as critical as communities around the world face diverse and novel risks that are changing the nature of communities themselves. To understand how to enhance community resilience, social-ecological systems literature suggests that resilience is to be understood as an emergent property of human-environment relationships (Walker and Salt 2012). This means that resilience is shaped by interactions between different components of a complex system that influence the mechanisms through which resilience occurs (Matin and Taylor 2015). However, there is a lack of empirical evidence illustrating resilience as an emergent property and how it relates to community resilience (Berkes and Ross 2013).

Enhancing community resilience has become a major focus of academic and policy analysis and practice in the fields of disaster risk reduction, conservation, climate change adaptation, and community development (Brown 2012, 2014). Yet, resilience is often viewed as a static property of individuals, communities, and wider systems (Cutter et al. 2008) and as the product of a set of discrete resilience-promoting capacities. However, understanding community resilience as the sum of its parts in this way fails to capture the complexity of the resilience concept (Quinlan et al. 2015) because the behavior of a dynamic system is not reducible to that of its individual components (Gunderson and Holling 2002). It is only by understanding the relationships between different components and how they interact to enable or constrain resilience that a clearer picture of community resilience can be drawn (Norris et al. 2008, Wilson 2012). This approach, from social-ecological systems and community development and disasters fields, also resonates with systems approaches developed in human developmental sciences, such as Bronfenbrenner's ecological systems theory (Bronfenbrenner 1989), and applied to understand community resilience as both a trait and a process (Boon et al. 2012). We refocus analysis of community resilience by examining the interlinking relationships between different resilience-promoting capacities to better inform both science and practice in supporting community ability to respond to different and multiple risks.

Research on community resilience represents a convergence between social-ecological systems thinking and developmental psychology and mental health fields (Brown and Westaway 2011). Community resilience is broadly defined as a community's collective capacity to function in, respond to, and potentially influence an environment characterized by continuous change, uncertainty, and crisis (Maclean et al. 2014). Existing studies in community development and psychology are instructive in emphasizing combinations of capacities that promote community resilience (e.g., Magis 2010, Ross et al. 2010). These include people-place relationships, knowledge and learning, social networks, collaboration, and leadership (Berkes and Ross 2013). This literature emphasizes the importance of understanding the links between capacities for community resilience (Buikstra et al. 2010). This is because community resilience occurs through these links in complex and often contradictory ways (Davidson 2010, Wilson 2012). Wilson (2012) suggests that resilience at the community level is forged at the intersection between different domains that characterize social-ecological systems. Kelly et al. (2015) show how relationships between natural, cultural, economic, social, and political factors are complex, cumulative, and easily disrupted, often undermining resilience. In the context of disaster risk management and community self-organization, Norris and colleagues (2008) posit how integrated sets of linked capacities, such as social capital and community competence, enable community resilience to a specific hazard by merging and rebounding in various ways and that individual capacities do not operate as separate entities. 
Table 1. Capacities assessed for community resilience

\begin{tabular}{|c|c|c|}
\hline Community resilience capacity & Description & Explanation \\
\hline Place attachment & $\begin{array}{l}\text { The affective, cognitive, and } \\
\text { material relationship that } \\
\text { people have with place }^{[1]}\end{array}$ & $\begin{array}{l}\text { Place attachment is shown to enhance community resilience }{ }^{[2]} \text { It is a motivating factor } \\
\text { for adaptation }{ }^{[3]} \text { based on its positive influence to maintain or enhance attributes of } \\
\text { place that are valued. }{ }^{[4]} \text { Yet, place attachment has limits in influencing adaptive } \\
\text { capacity. }{ }^{[5]} \text { This can weaken resilience levels through desire to live in high-risk areas }{ }^{[6]} \\
\text { and negation to accept new ideas and practices. }{ }^{[7]}\end{array}$ \\
\hline Leadership & $\begin{array}{l}\text { People (leaders, entrepreneurs, } \\
\text { champions), organizations, } \\
\text { characteristics, roles, and } \\
\text { actions that affect outcomes }{ }^{[8]}\end{array}$ & $\begin{array}{l}\text { Exploring the role of leadership for community resilience is recognised as important for } \\
\text { effective community action in light of change. }{ }^{[9]} \text { However, attributing governance } \\
\text { outcomes to the presence or absence of leadership is not sufficient for resilience. }{ }^{[10]} \\
\text { Understanding how it emerges, evolves, or practically achieves results such as knowledge } \\
\text { and trust building is critical. } .^{111]}\end{array}$ \\
\hline Community networks & $\begin{array}{l}\text { The bonding and bridging ties } \\
\text { that enable people to act } \\
\text { collectively }{ }^{2[2]}\end{array}$ & $\begin{array}{l}\text { Community resilience is strengthened through access to diverse networks (i.e., the } \\
\text { different combinations of bonding and bridging network ties) }{ }^{[13]} \text { This is because they } \\
\text { provide essential support, help identify new opportunities, and provide a focus for } \\
\text { renewed optimism and hope during times of change. }{ }^{[14]}\end{array}$ \\
\hline $\begin{array}{l}\text { Community cohesion and } \\
\text { efficacy }\end{array}$ & $\begin{array}{l}\text { Community ability to act } \\
\text { together and belief in one's } \\
\text { own ability to perform a task } \\
\text { and manage prospective } \\
\text { situations }\end{array}$ & $\begin{array}{l}\text { Community cohesion and efficacy enhances community resilience as it supports } \\
\text { community ability to act independently and make one's own free choices. It is linked to } \\
\text { the agency of a community, highlighting the unique role a community plays in } \\
\text { developing its own level of resilience. }\end{array}$ \\
\hline Knowledge and learning & $\begin{array}{l}\text { Individual and group capacity } \\
\text { to respond to local needs and } \\
\text { issues }\end{array}$ & $\begin{array}{l}\text { Conscious undertaking of different types and forms of knowledge and learning are key } \\
\text { to community ability to respond to change. }{ }^{[18]} \text { This includes iterative, continuous, and } \\
\text { reflective learning, }{ }^{[19]} \text { and learning from past crisis to enhance social memory. }{ }^{[20]}\end{array}$ \\
\hline \multicolumn{3}{|c|}{ 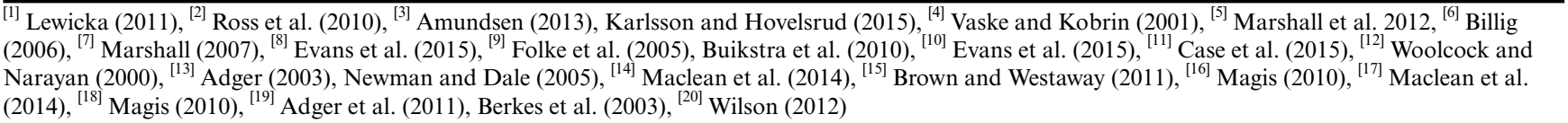 } \\
\hline
\end{tabular}

Reviewing literature on resilience from diverse fields, including human development, social-ecological systems, community development, and disasters, Brown and Westaway (2011) identify parallel evolutions in thinking. First, there has been an important shift away from the idea that resilience and adaptive capacity can be reduced to a simple measure or index. Across each of these fields, there has been a realization of the relational and subjective aspects of resilience. Secondly, there is recognition of the dynamic and cross-scale aspects of resilience. For example, in developmental psychology, this has involved emphasis on "ecological" models such as Schoon's multidimensional model of resilience (Schoon 2006). Finally, there have been parallel moves away from deficit models toward identifying capacities for resilience. For example, Almedom (2008), from a health and social care perspective, charts a progressive paradigm shift from the disease-driven inquiries on risk and vulnerability to healthcentered approaches to building resilience to disasters and preventing vulnerability to disease, social dysfunction, and human and environmental resource depletion. Although the starting points of these fields are very different-for example, development psychology focuses on individual outcomes in the face of known risk factors compared with a social-ecological systems perspective - there is strong resonance around the need to understand dynamic and relational processes and how they affect resilience. For example, Masten and Obradovic (2008) use the findings from research in human development to argue for a resilience framework for disaster planning within which agency and self-efficacy are seen as important attributes that enable individuals and communities to plan, persist, and adapt in the face of disasters and other events. We use this convergence across these literatures to inform our research design and our approach to understanding community resilience and to identify the specific gap we aim to fill.

Although resilience is often examined in relation to specific risks or hazards, resilience also relates to the capacity to respond to a range of different and novel disturbances (Walker and Salt 2012). The distinction has been made between specific resilience and general resilience (Folke et al. 2010, Carpenter et al. 2012). Understanding resilience in this way moves away from a more conventional risk approach, which involves identifying or quantifying a known risk, and embraces uncertain and multivariate risks and fast and slow drivers of change. Overall, less work on how resilience-promoting capacities enable community resilience to multiple and different risks has been undertaken (Berkes and Ross 2013). When facing uncertain and multivariate risks, building resilience via different strategies and through different capacities is a common strategy among governments, nongovernmental organizations (NGOs), and other agencies. This parallels, for example, developments in disaster risk reduction, which are moving away from specific risk approaches to resilience building. We focus on understanding how these capacities work together to support resilience and we include both subjective and relational aspects of resilience. But we are primarily interested in how people evaluate the role of and importance of different capacities in conferring resilience. Based on a thorough literature review, we build on previous studies identifying the importance of five capacities for community resilience (Table 1) to analyze how these capacities combine for communities experiencing a range of different risks so that we can understand how they contribute to the emergence of 
resilience. These capacities are place attachment, leadership, community cohesion and efficacy, community networks, and knowledge and learning.

In this paper, we add to and enrich the existing theoretical and conceptual literature on community resilience by presenting an analysis of resilience as an emergent property of communities in north Cornwall, UK. Our aim is not to measure community resilience, rather understanding resilience as an emergent property or process of communities, we seek to (1) assess a set of five empirically researched capacities to investigate their relevance for resilience to combined multiple risks according to subjective perceptions of residents living in two coastal locations, and (2) explore the interlinkages between these capacities to understand how they interact to confer community resilience.

\section{THE CONTEXT: NORTH CORNWALL, UK}

Research was conducted in two coastal locations in north Cornwall, UK, during June and July 2014. Cornwall is a county located in the southwest UK, with a total land area of $3,563 \mathrm{~km}^{2}$ and a population of just over half a million people (Cornwall Council 2014). Cornwall has a long coastline $(475 \mathrm{~km})$ and a history linked to maritime activities. Tourism accounts for $24 \%$ of gross domestic product (House of Commons 2008). Cornwall is subject to winter storms, caused by Atlantic low pressure systems, and intense rainfall events in the summer.

Boscastle and Wadebridge (Fig. 1) were selected specifically as our research sites as they provide good testing grounds for resilience and encompass different population sizes and past experience of a shock event. Both communities experience a wide range of similar risks (Table 2), which reflect the broader coastal Cornish context and other towns in the north Cornwall area. However, these risks play out differently in each location. Enhancing community resilience is regarded as desirable not only due to environmental risks such as extreme weather events (linked in part to climate change), but also to other risks that are more immediate, including economic stagnation, loss of livelihoods, new development, and dependence on tourism (Cornwall Strategic Partnership 2008). Wadebridge is the larger of the two communities we studied, with a population of 6,599 people compared with 641 people in Boscastle (UK National Statistics 2011). One field site (Boscastle) experienced a flash flood in the last 12 years. Both Boscastle and Wadebridge are located in the Cornwall Area of Outstanding Natural Beauty. Wadebridge is historically a market town, located on the Camel Estuary, which leads out to sea. Boscastle is a village and fishing port located in a natural inlet on the coast. The physical beauty of each town attracts a high number of tourists, especially during the summer months.

\section{METHODS}

Data were gathered in two stages using a mixed methods approach (Table 3). First, a survey was used to elicit perceptions of residents in Boscastle and Wadebridge on the importance of the five capacities assessed for community resilience and what factors characterized each capacity, using a structured questionnaire. Second, the survey was followed by focus group discussions with residents in each town who had completed the survey to probe for a deeper understanding of the causal relationships and dynamic processes between capacities and community resilience.
Fig. 1. Location of Boscastle and Wadebridge, north Cornwall, UK.

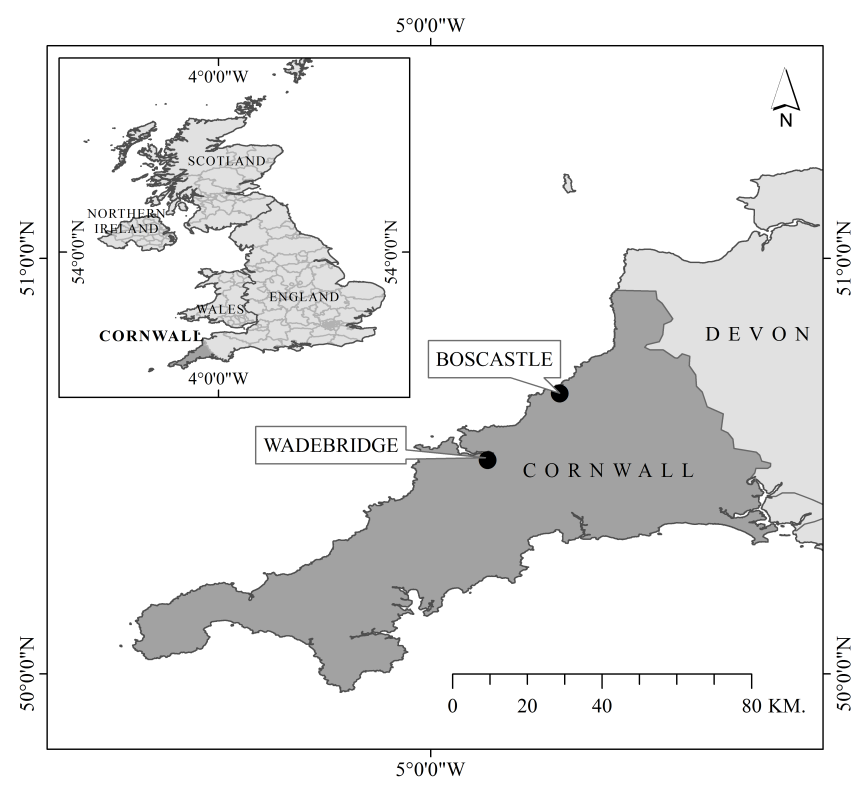

Table 2. Key risks for communities in Boscastle and Wadebridge (Cornwall Strategic Partnership 2008, Cornwall Council 2014, Majevadia 2016)

\begin{tabular}{ll}
\hline \hline $\begin{array}{l}\text { Environmental } \\
\text { risks }\end{array}$ & Contextual risks \\
\hline $\begin{array}{l}\text { Winter storms } \\
\text { Heavy rainfall } \\
\text { episodes } \\
\text { Tidal surges }\end{array}$ & $\begin{array}{l}\text { Government cuts in flood and sea defense budgets } \\
\text { High dependence on summer tourism }\end{array}$ \\
& $\begin{array}{l}\text { Low wages compared with rest of the UK and lack of } \\
\text { diverse employment opportunities, resulting in loss of } \\
\text { youth }\end{array}$ \\
Spring tides & $\begin{array}{l}\text { Increasing ageing population and influx of retirees } \\
\text { moving in }\end{array}$ \\
& $\begin{array}{l}\text { Despite expansion in housing stock, there is a shortage } \\
\text { of affordable housing for the local population } \\
\text { Pressures on infrastructure from populations attracted } \\
\text { by new housing, including roads and schools }\end{array}$ \\
& $\begin{array}{l}\text { Increasing fragmentation within communities, decline } \\
\text { of shared community activity, and social isolation } \\
\text { Lack of public transport and poor transport } \\
\text { connectivity, resulting in geographic isolation } \\
\text { Shift in local service provision to regional institutions, } \\
\text { resulting in less effective services } \\
\text { Sustaining local commercial independence }\end{array}$ \\
\hline
\end{tabular}

We brought a survey together with focus groups by using the survey to initially identify which elements of community resilience were particularly salient for participants at each site. This then in turn helped guide focus group discussions by highlighting important topics for detailed analysis (Morgan 1996). Contextual information from the surveys shaped the design of focus group questions, ensuring that they were relevant for both towns, and created the structure in which participants were able to discuss in 
Table 3. Data collection in Boscastle and Wadebridge

\begin{tabular}{|c|c|c|c|c|}
\hline & Data type & Number undertaken & $\begin{array}{l}\text { Stakeholders } \\
\text { represented }\end{array}$ & Example Likert scale survey statements and focus group questions asked \\
\hline Stage 1 & $\begin{array}{l}\text { Survey with } \\
\text { individual residents }\end{array}$ & $\begin{array}{l}170 \text { in total: } 70 \text { in } \\
\text { Boscastle (out of a } \\
\text { total of } 345 \\
\text { households) } \\
100 \text { in Wadebridge } \\
\text { (out of a total of } \\
2,724 \text { households) }\end{array}$ & $\begin{array}{l}\text { Retirees, tourist } \\
\text { industry, and retail } \\
\text { personnel, self- } \\
\text { employed individuals, } \\
\text { charity } \\
\text { representatives, } \\
\text { Church leaders, } \\
\text { teachers, community } \\
\text { decision makers }\end{array}$ & $\begin{array}{l}\text { Place attachment: This place is a part of myself } \\
\text { Leadership: } \\
\text { My community has effective leaders } \\
\text { Community networks: people in my community are friends with their } \\
\text { neighbors } \\
\text { Community cohesion and efficacy: people in my community trust each } \\
\text { other } \\
\text { Knowledge and learning: my community looks at its successes and } \\
\text { failures so it can learn from the past } \\
\text { Overall perceptions of community resilience: to what extent do you agree } \\
\text { with the following statement: My community's level of resilience is high. }\end{array}$ \\
\hline Stage 2 & $\begin{array}{l}\text { Community focus } \\
\text { groups }\end{array}$ & $\begin{array}{l}\text { Two in total: } \\
\text { One in Boscastle, } \\
\text { one in Wadebridge }\end{array}$ & $\begin{array}{l}\text { Same as in Stage } 1 \\
\text { above }\end{array}$ & $\begin{array}{l}\text { Residents state in the survey that they have a strong attachment to this } \\
\text { place. How important is this attachment for enhancing community } \\
\text { resilience? } \\
\text { Out of these five factors, what order of importance would you rank them } \\
\text { in from } 1-5 \text { for building community resilience (with } 1 \text { being the most } \\
\text { important)? Why? }\end{array}$ \\
\hline
\end{tabular}

${ }^{[1]}$ Oxford Consultants for Social Inclusion (OCSI) 2009a

${ }^{\text {[2] }}$ OCSI 2009b

depth the links and emergent qualities of different community resilience capacities. Participants were not asked specifically about different risks or resilience applied to different risks as our approach to understanding resilience took a more holistic view.

We wanted to understand the dynamic process of how community resilience is conferred. Hence our objective of using mixed methods was to combine insights of several methods that are more likely to produce a robust understanding of community resilience, given it is an abstract concept that defies direct observation (Ross and Berkes 2014). Using a survey with focus groups in particular is advantageous for our study. Focus groups provide insight into complex interactions and generate new collective understandings from participant contributions (Morgan and Krueger 1993, Ross and Berkes 2014). The strengths of a focus group approach complemented our intention to facilitate focus groups to elicit a deeper understanding of resilience as an emergent property in each locality.

Respondents were selected to complete surveys based on a doorto-door random sampling technique with every third household where feasible (Henry 1990). To ensure that oversampling in one particular area of the community did not occur and that a range of different risks and experiences were drawn upon, surveys were undertaken with equal numbers of residents where possible in three sublocations within each field site.

The survey contained 37 fixed statements adapted from validated versions of Likert scales presented in the literature related to the community resilience capacities being studied (Lewicka 2008, Pfefferbaum et al. 2011, Leykin et al. 2013). Respondents were asked to rate how strongly they agreed with each statement using a five-point Likert scale ( $1=$ strongly disagree, $2=$ disagree, $3=$ neither disagree or agree, $4=$ agree, $5=$ strongly agree). Respondents could leave a response blank if desired. The survey took up to 25 minutes to complete and was facilitated by the lead author. The survey was pilot-tested to ensure statement understanding and ease of response.
Questions asked in focus groups encouraged participants to freely discuss how the five capacities were linked and why their interactions influenced resilience. Established protocols for effective focus groups were followed (MacDougall and Fudge 2001, Berg 2014). This ensured focus group size and composition was appropriate and sufficiently diverse to encourage the rich discussion that our research required (Bloor et al. 2011). Focus groups were not representative of the broader community in each study site but designed to capture the diversity of each community. Focus groups comprised seven residents in Boscastle and four in Wadebridge. Participants included male and female participants of different ages, from diverse sociodemographic groups, and both long- and short-term residents. Attendance was based on availability and interest. The same question guide was used in both focus groups. They were audio recorded and transcribed.

Two techniques were used to examine the perceived importance of selected capacities in promoting community resilience and the comparative relationships between them. First, responses to survey statements were analyzed using statistical methods of oneway analysis of variance (ANOVA), independent samples t-test, and Mann-Whitney U Test with Statistical Package for Social Sciences (SPSS version 21). Second, manual deductive (Miles and Huberman 1994) and inductive coding (Strauss 1987) was undertaken to analyze focus group discussion transcripts. Thematic analysis was conducted through a detailed interrogation of focus group material according to preconceived and emerged topics that arose during the research process.

\section{RESULTS AND DISCUSSION}

Our results show that respondents in both locations perceive place attachment to be the most important capacity for community resilience (Table 4). All respondents in focus group discussions agreed on the primacy of place. This is exemplified by respondent 5 in Boscastle: 
Table 4. Mean scores from resident survey showing perceived importance of community resilience capacities in Boscastle $(n=$ $70)$ and Wadebridge $(n=100)$.

\begin{tabular}{|c|c|c|c|c|}
\hline \multirow{2}{*}{$\begin{array}{l}\text { Community resilience } \\
\text { capacities }\end{array}$} & \multicolumn{2}{|c|}{ Boscastle } & \multicolumn{2}{|c|}{ Wadebridge } \\
\hline & Mean & $\begin{array}{l}\text { Std. } \\
\text { Error }\end{array}$ & Mean & $\begin{array}{l}\text { Std. } \\
\text { Error }\end{array}$ \\
\hline Place attachment & 4.484 & 0.049 & 4.183 & 0.060 \\
\hline $\begin{array}{l}\text { Community cohesion and } \\
\text { efficacy }\end{array}$ & 4.105 & 0.059 & 3.831 & 0.051 \\
\hline Community networks & $3 ., 911$ & 0.061 & 3.750 & 0.046 \\
\hline Knowledge and learning & 3.878 & 0.062 & 3.431 & 0.051 \\
\hline Leadership & 3.382 & 0.070 & 3.259 & 0.060 \\
\hline
\end{tabular}

When people are attracted to the same place, it strengthens community resilience as caring about where you live builds resilience. It's about loyalty to a place. It breeds commitment to it...if something happens, the community gets together and does something as needed.

In terms of importance of community resilience capacities, place attachment is followed by community cohesion and efficacy; community networks; knowledge and learning; and lastly, leadership (Table 4).

Figures 2 and 3 show diagrammatically the dynamic and emergent nature of community resilience in each location and provide insight into each source of resilience and how they are linked and collectively contribute to community resilience. The numbering of each capacity reflects their perceived significance in facilitating community resilience and is particular to each context. Each capacity is necessary to support the development of the capacity that proceeds from it. Place attachment is shown to be instrumental in mobilizing the community resilience by providing the foundation upon which other capacities for community resilience depend. As highlighted by respondent 5, place attachment enhances perceptions of community cohesion and efficacy, which all residents consider to be the second most significant capacity for conferring resilience.

This highlights two key findings. First, it supports calls to better understand the significance of place attachment for community resilience (Berkes and Ross 2013). Our results build on studies that identify place attachment as strengthening community resilience (e.g., Amundsen 2013) to elucidate its key role and emergent nature. Place attachment forms the backbone supporting interactions between other individual capacities, and hence, provides a starting point for community resilience. Second, our results provide insight into collective capacity compared with individual capacity for community resilience. Place attachment is experienced at the individual level but it is reflected at the community level through shared experience between respondents that brings the community together. As stressed by respondent 5 , attachment to place provides a catalyst for individuals to come together as a community based on their shared experience of the place where they live, which in turn supports perceived levels of community cohesion and efficacy. This resonates with community development and natural resources sociology literature that shows when local people care about each other and the place they live, community agency can emerge as the capacity of local people to unite and potentially act is increased (Theodori 2004, Brennan et al. 2005).

Fig. 2. Prioritization of community resilience capacities from resident perceptions in Boscastle on a scale of 1 to 5 (number 1 represents the most important capacity for community resilience, and number 5 represents the least important).

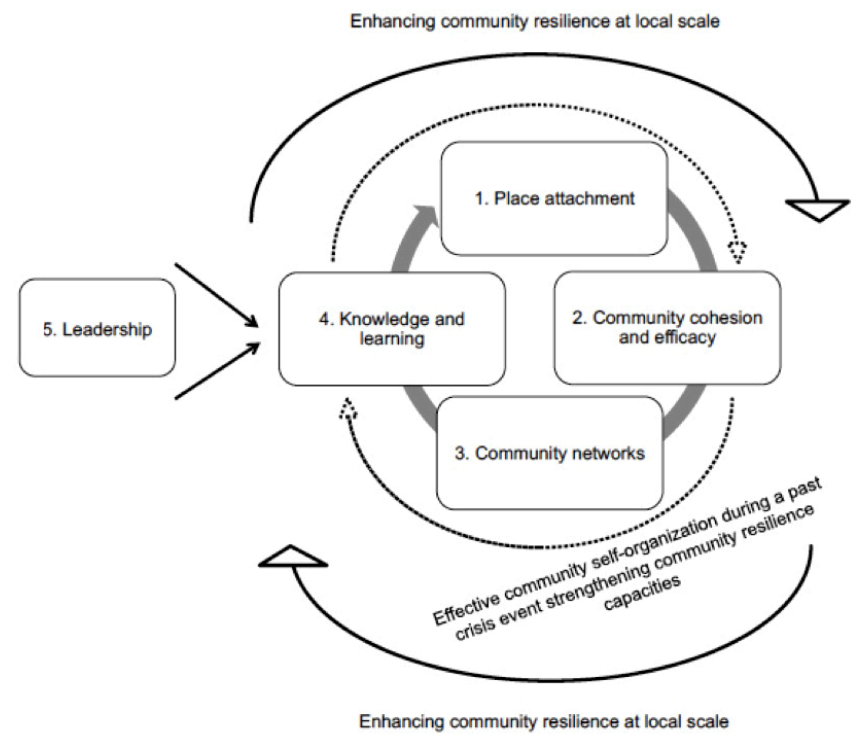

Fig. 3. Prioritization of community resilience capacities from resident perceptions in Wadebridge on a scale of 1 to 5 (number 1 represents the most important capacity for community resilience, and number 5 represents the least important).

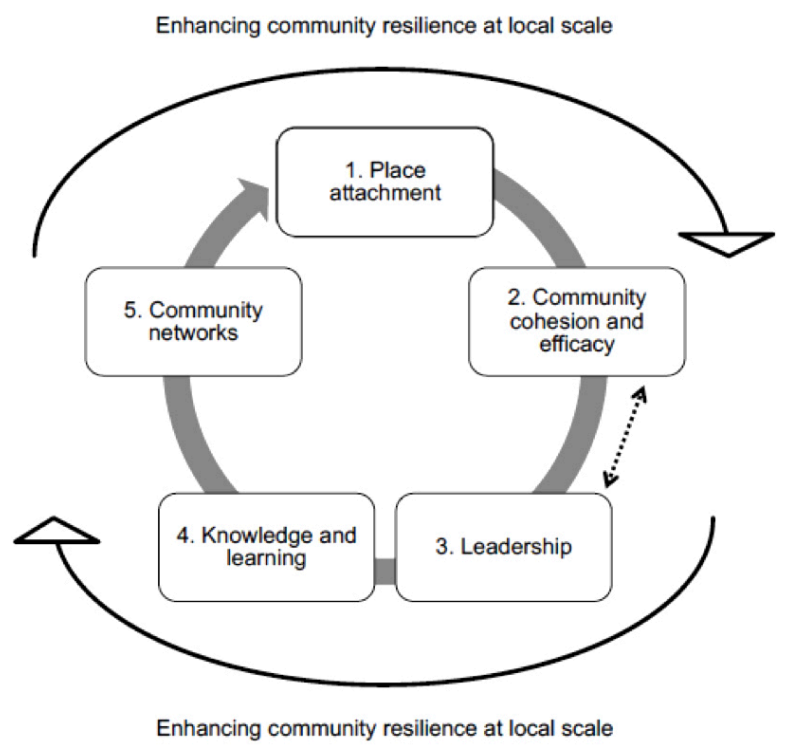


Our research shows that there could be both positive and negative elements to this finding on place attachment for community resilience. Place attachments are not uniform across communities. We know from the literature that different social groups, for example, second homeowners and local residents, attach different meanings to places (Stedman 2006, Rey-Valette et al. 2015). With increasing mobility, the demographics of communities are changing, prompting realignment of relationships between communities and their local place (Kelly and Hosking 2008). Our results suggest that understanding this dynamism of place attachment is important in understanding the evolution of community resilience in a broader context of social change.

Our research also provides insights into the role of leadership and its different functions in each location. Survey results from both sites show that leadership was valued as the least important capacity for conferring community resilience (Table 4). Yet, qualitative data from focus group discussions in Wadebridge demonstrate that leadership is perceived to be a central component in enabling resilience. The dotted arrow in Fig. 3 shows that the role of leadership is perceived to be transferable compared with the other capacities. Importantly, leadership is ambiguous in how it interacts with other capacities, which has implications for how it contributes to community resilience. As illustrated by respondent 81 from Wadebridge, leadership can be an enabler or an outcome of other community capacities, depending on circumstances:

Community cohesion and efficacy can support identifying appropriate leadership that will further foster community unity and ability to get things done. On the other hand, effective leadership may be required to support community cohesion and efficacy to begin with.

Community resilience is viewed differently in Boscastle. Leadership was not considered a necessary element of community resilience. As observed by respondent 17, this reflects respondents' feelings that there is a capacity to self-organize when needed, based on the experience of a disruptive event in the past decade:

There are enough capable people in the community anyway. Someone always steps up when needed. The floods we experienced in 2004 have shown us that individuals take the reins in a crisis.

Focus group participants in Boscastle perceive leadership to sit outside of the main community resilience dynamic (Fig. 2). Here, leadership is used in a conditional sense where its importance and role are legitimized from within the community itself. Accordingly, the presence and style of leadership change to suit circumstances, and residents do not perceive any one particular fixed style or role of leadership (Walker and Salt 2012). This result gives insights into the relationship between leadership and selforganization, suggesting that community self-organization happens despite leadership, with strong levels of community resilience still perceived.

The role of leadership in community resilience also depends on the type of leadership. Evidence from Wadebridge and Boscastle suggests there is a difference between leadership that arises from within the community itself and that which is conferred more formally from outside the community in promoting community resilience. For example, recent changes to formal (administrative and political) local government are shown to weaken perceived levels of community resilience overall, with formal leadership distrusted by communities. As explained by respondent 95 in Wadebridge, a shift from local council to a centralized unitary council for the whole county of Cornwall raises concerns:

Cornwall is a diverse county. No two locations are the same, so centralized institutional power is not supportive for building community resilience. The decision to make Cornwall one council will weaken resilience over time as communities in different locations have different individual needs...it has been a big step back for Wadebridge and Cornwall at large.

This result contrasts with much resilience literature that promotes leadership as important for conferring resilience, whereas highlighted by respondent 95 above, although formal leadership exists, it is seen to constrain community resilience rather than facilitate it. Overall, our results suggest that leadership for community resilience has to come from the community and be generated by community needs rather than formally conferred on people outside of the community.

We interpret this result to mean that there is no universal mechanism for enabling community resilience (Matin and Taylor 2015). Context matters, and the dynamics of community resilience in any location is influenced by an appropriate combination of capacities (Biggs et al. 2012). Respondents in Boscastle and Wadebridge draw on the capacities highlighted in this study in different ways, leading to different formulations of agency and self-organization that are perceived to strengthen resilience at the local level. This means that developing any one capacity in isolation from others is unlikely to lead to enhanced levels of community resilience. Rather, community resilience occurs through the relationships between capacities that together foster resilience (Norris et al. 2008, Wilson 2012). Leadership, for example, is not to be seen as a standalone capacity, and community resilience is not dependent on any single capacity (Hegney et al. 2008). Individual capacities need to be assessed in terms of how they combine and function together to enable or constrain community resilience.

Different capacities interrelate and interact to change local perceptions of risk that enhance perceived levels of community resilience. In Boscastle, past experience of a flooding event is viewed as an important factor. Residents draw on their perceived strength of effective historical capacity to act and self-organize around a past crisis event. As shown by the circular dotted arrow in Fig. 2, this attribute acts like an additional component in resilience building. It interacts together with the other capacities to enhance their perceived strength. This in turn influences how capacities combine to contribute to resident perceptions of higher overall resilience to different and multiple risks (Table 5) and also higher perceived resilience in relation to each capacity compared with residents in Wadebridge (Table 4). For example, as illustrated by respondent 65 in Boscastle, effective local response to the 2004 flood crisis is perceived to enhance current notions of place attachment. This then feeds into respondents' perceptions of strengthened levels of community cohesion and efficacy and bonding social networks that support latent perceived capacity to respond to future disturbance: 


\begin{abstract}
[The 2004 flood crisis] gave a shared focus of safety for the community... a way forward for the future that has strengthened people's connection [to Boscastle]. If another crisis was to happen again, it would be the same people united...it was a shared experience across the community that opened up the community. I know more people now due to the flood than before.
\end{abstract}

Table 5. Results from survey showing residents in Boscastle perceive having higher levels of community resilience than residents in Wadebridge

\begin{tabular}{llccc}
\hline \hline Survey Question & Study site & N & $\begin{array}{c}\text { Mean } \\
\text { rank }\end{array}$ & $\begin{array}{c}\text { Sum of } \\
\text { ranks }\end{array}$ \\
\hline My personal level of & Boscastle & 70 & 98.60 & 6902.00 \\
resilience is high & Wadebridge & 100 & 76.33 & 7633.00 \\
& Total & 170 & & \\
My community's level of & Boscastle & 70 & 105.31 & 7371.50 \\
resilience is high & Wadebridge & 100 & 71.64 & 7163.50 \\
& Total & 170 & & \\
\hline
\end{tabular}

This suggests that residents perceive community resilience to be strengthened in response to a disturbance rather than the absence of it (Khanlou and Wray 2014). Past experience of a crisis event shapes local narratives around resilience, which influences perceptions of the strength of community capacity to respond to risk. Our results suggest that this may be attributed in part to evidence of the inoculation effect (Eysenck 1983, Norris and Murrell 1988). Thus, residents in Boscastle may perceive themselves to be more resilient to a particular crisis event because of their psychological ability to cope better with it based on previous life experience of it. These results also hint at Rebecca Solnit's observation (2009) that purposefulness, connectedness, and even joy sometimes accompany disasters. This suggests that certain aspects of people's well-being may be positively affected as a result of shared experience of hardship, for example, through a stronger sense of community or social capital, as articulated by respondent 65 above.

We find that to understand community resilience, we need to analyze these intricate and dynamic relationships between different capacities and how, together, they inform resilience. None of the capacities assessed in this study are universally beneficial, and all require a nuanced understanding of how, when, and where they apply, as well as how they interact with or depend on other capacities (Biggs et al. 2012: 440). We illustrate how different capacities fit together and how their dynamics operate, with our results showing resilience to be experiential and responsive. As a property of a complex social-ecological system that facilitates or constrains what people can do in response to change (Matin and Taylor 2015), resilience is dynamic, nuanced, socially contingent, and context specific. We also show resilience to be a property of a self-organizing and self-regulating system, and our results indicate emergence in how specific events bring communities together to build resilience. Our results thus inform and advance Norris and colleagues' (2008) framework illustrating community resilience as a set of interlinked capacities to empirically show community resilience as an emergent property.
Our contribution is to empirically explore how the concept of emergence from social-ecological systems literature informs understanding of community resilience research, as suggested by authors in the field, such as Davidson (2010), Berkes and Ross (2013), and most recently, Maclean et al. (2016).

\section{CONCLUSION}

In line with other scholars (e.g., Matin and Taylor 2015), we define resilience as an emergent property of a complex and dynamic system forged by diverse relationships between a set of resilienceenhancing capacities that together contribute to enabling or constraining community resilience in different ways, depending on the context.

Our research builds on past studies on community resilience that present typologies of resilience-promoting capacities to show the transactional links in operation between them. We find that there is no universal mechanism or "silver bullet" for enabling community resilience. Context is important because the combination and links between individual capacities emerge differently and confer community resilience in diverse ways. Our research shows that the ordering of capacities, the links, and causal patterns for resilience change in each community as residents draw on them in distinct combinations. Communities view which capacities are important for strengthening their resilience quite differently. Our study provides some insight into the dynamics of resilience and resilience building, and what enablers and constraints people perceive, as well as their agency and efficacy to influence change.

For example, we have learned that leadership is viewed differently and assumes a different function in each community. It can be an enabler or an outcome of other community capacities, or, conversely, it can wield little influence over resilience as community self-organization is shown to occur despite it. Similarly, community ability to self-organize around a past crisis event acts as an additional catalyst in resilience building. How it interrelates with other capacities changes local perceptions of risk. It enhances perceived levels of overall community resilience for residents in Boscastle, as well as for each individual capacity. Place attachment is shown to be integral to community resilience in both locations by providing a foundation for interactions between other capacities, and as a starting point into understanding the emergent nature of community resilience. It is also shown to construct collective capacity for community resilience compared with individual capacity by providing impetus for individuals to come together as a community based on their shared experience of the place where they live.

Our findings have implications for community resilience assessment or measurement. Given the heightened interest in community resilience, there is a need to be explicit about what is evaluated. Viewing any one capacity in isolation, or even developing complex indices based on composite capacities, is unlikely to adequately capture the complex, dynamic, and emergent nature of community resilience. To reflect this, we propose to undertake analysis to elucidate how different capacities overlap, combine, and work together to enhance resilience to different and multiple risks. 
Responses to this article can be read online at: http://www.ecologyandsociety.org/issues/responses. php/9784

\section{Acknowledgments:}

The authors thank respondents in Boscastle and Wadebridge for engaging in this research. This work was supported by the Natural Environment Research Council (NERC) through Belmont Forum project, Multi-scale Adaptations to Global Change in Coastlines (MAGIC) project no: NE/L008807/1, and by the Economic and Social Research Council (ESRC) through the UK South West Doctoral Training Centre Studentship Award 2013 (Environment, Energy and Resilience). Any data collected under MAGIC will be available in the appropriate prescribed data depositories, following NERC guidelines, after the conventional embargo period. Qualitative data are anonymized and usually in narrative form.

\section{LITERATURE CITED}

Adger, W. N. 2003. Social capital, collective action, and adaptation to climate change. Economic Geography 79(4):387404. http://dx.doi.org/https://doi.org/10.1111/j.1944-8287.2003. $\underline{\mathrm{tb} 00220 . \mathrm{x}}$

Adger, W. N., K. Brown, D. R. Nelson, F. Berkes, H. Eakin, C. Folke, K. Galvin, L. Gunderson, M. Goulden, K. O'Brien, J. Ruitenbeek, and E. L. Tompkins. 2011. Resilience implications of policy responses to climate change. Wiley Interdisciplinary Reviews: Climate Change 2.5:757-766. http://dx.doi.org/10.1002/ $\underline{\text { wcc. } 133}$

Almedom, A. M. 2008. Resilience research and policy/practice discourse in health, social, behavioral, and environmental sciences over the last ten years. African Health Sciences 8:S5-13.

Amundsen, H. 2013. Place attachment as a driver of adaptation in coastal communities in northern Norway. Local Environment: The International Journal of Justice and Sustainability 20(3):237276. http://dx.doi.org/10.1080/13549839.2013.838751

Berg, B. L. 2014. Qualitative research methods for the social sciences. Eighth edition. Pearson Education Ltd., Harlow, UK.

Berkes, F., J. Colding, and C. Folke, editors. 2003. Navigating social-ecological systems: building resilience for complexity and change. Cambridge University Press, Cambridge, UK. http://dx. doi.org/10.1017/CBO9780511541957

Berkes, F., and H. Ross. 2013. Community resilience: toward an integrated approach. Society and Natural Resources 26(1):5-20. http://dx.doi.org/10.1080/08941920.2012.736605

Biggs, R., M. Schlüter, D. Biggs, E. L. Bohensky, S. BurnSilver, G. Cundill, V. Dakos, T. M. Daw, L. S. Evans, K. Kotschy, A. M. Leitch, C. Meek, A. Quinlan, C. Raudsepp-Hearne, M. D. Robards, M. L. Schoon, L. Schultz, and P. C. West. 2012. Toward principles for enhancing the resilience of ecosystem services. Annual Review of Environmental Resources 37:421-448. http://dx. doi.org/10.1146/annurev-environ-051211-123836

Billig, M. 2006. Is my home my castle? Place attachment, risk perception, and religious faith. Environment and Behavior 38:248265. http://dx.doi.org/10.1177/0013916505277608
Bloor, M., J. Frankland, M. Thomas, and K. Robson. 2011. Focus groups in social research. SAGE Research Methods, SAGE, London, UK. http://dx.doi.org/10.4135/9781849209175

Boon, H. J., A. Cottrell, D. King, R. B. Stevenson, and J. Millar. 2012. Bronfenbrenner's bioecological theory for modelling community resilience to natural disasters. Natural Hazards 60 (2):381-408. http://dx.doi.org/10.1007/s11069-011-0021-4

Brennan, M. A., A. E. Luloff, and J. C. Finley. 2005. Building sustainable communities in forested regions. Society and Natural Resources 18(9):779-789. http://dx.doi.org/10.1080/08941920500205376

Bronfenbrenner, U. 1989. Ecological systems theory. Annals of Child Development 6:187-249.

Brown, K. 2012. Policy discourses of resilience. Pages 37-50 in M. Pelling, D. Manuel-Navarrete, and M. Redclift, editors. Climate change and the crisis of capitalism. Routledge, Abingdon, UK. http://dx.doi.org/https://doi.org/10.1177/0309132513498837

Brown, K. 2014. Global environmental change. I: A social turn for resilience? Progress in Human Geography 38(1):107-117.

Brown, K., and E. Westaway. 2011. Agency, capacity, and resilience to environmental change: lessons from human development, well-being, and disasters. Annual Review of Environment and Resources 36:321-342. http://dx.doi.org/10.1146/ annurev-environ-052610-092905

Buikstra, E., H. Ross, C. A. King, P. G. Baker, D. Hegney, K. Mclachlan, and C. Rogers-Clark. 2010. The components of resilience: perceptions of an Australian rural community. Journal of Community Psychology 38:975-991. http://dx.doi.org/10.1002/ jcop.20409

Carpenter, S., K. Arrow, S. Barrett, R. Biggs, W. Brock, A.-S. Crépin, G. Engström, C. Folke, T. Hughes, N. Kautsky, C.-Z. Li, G. McCarney, K. Meng, K-G. Mäler, S. Polasky, M. Scheffer, J. Shogren, T. Sterner, J. Vincent, B. Walker, A. Xepapadeas, and A. Zeeuw. 2012. General resilience to cope with extreme events. Sustainability 4(12):3248-3259. http://dx.doi.org/10.3390/su4123248

Case, P., L. S. Evans, M. Fabinyi, P. J. Cohen, C. C. Hicks, M. Prideaux, and D. M. Mills. 2015. Rethinking environmental leadership: the social construction of leaders and leadership in discourses of ecological crisis, development, and conservation. Leadership 11(4):396-423. http://dx.doi.org/10.1177/1742715015577887

Cornwall Council. 2014. Cornwall and Isles of Scilly strategic economic plan. Parsons Brinckerhoff, Truro, Cornwall, UK. [online] URL: http://www.cioslep.com/assets/file/Strategic $\%$ 20Economic $\% 20$ Plan/technical $\% 20$ reports $/ 2014 \% 2003 \% 2031 \%$ 20Transport $\% 20$ Annex $\% 20$ Report $\% 2012 \% 20$ Cornwall $\% 20$ Bus $\%$ 20Network $\%$ 20Business $\% 20$ Case $\%$ 20FINAL.pdf

Cornwall Strategic Partnership. 2008. Sustainable community strategy for Cornwall. Shaping Cornwall's future. Cornwall Strategic Partnership, Truro, Cornwall, UK. [online] URL: $\underline{\text { http:// }}$ www.ibyd.co.uk/bhf/documents/Cornwall and Isles Of Scilly PCT/ LSP.pdf

Cutter, S. L., L. Barnes, M. Berry, C. Burton, E. Evans, E. Tate, and J. Webb. 2008. A place-based model for understanding community resilience to natural disasters. Global Environmental Change 18(4):598-606. http://dx.doi.org/10.1016/j.gloenvcha.2008.07.013 
Davidson, D. J. 2010. The applicability of the concept of resilience to social systems: some sources of optimism and nagging doubts. Society and Natural Resources 23:1135-1149. http://dx.doi. org/10.1080/08941921003652940

Evans, L. S., C. C. Hicks, P. J. Cohen, P. Case, M. Prideaux, and D. M. Mills. 2015. Understanding leadership in the environmental sciences. Ecology and Society 20(1): 50. http://dx.doi.org/10.5751/ ES-07268-200150

Eysenck H. J. 1983. Stress, disease, and personality: the "inoculation effect" Pages 121-146 in C. L. Cooper, editor. Stress research: issues for the eighties. Wiley, New York, New York USA.

Folke, C., S. R. Carpenter, B. H. Walker, M. Scheffer, F. S. Chapin, III, and J. Rockstrom. 2010. Resilience thinking: integrating resilience, adaptability, and transformability. Ecology and Society 15(4):20. http://dx.doi.org/10.5751/ES-03610-150420

Folke, C., T. Hahn, P. Olsson, and J. Norberg. 2005. Adaptive governance of social-ecological systems. Annual Review of Environment and Resources 30:441-473. http://dx.doi.org/10.1146/ annurev.energy.30.050504.144511

Gunderson, L. H., and C. S. Holling, editors. 2002. Panarchy: understanding transformations in human and natural systems. Island Press, Washington, D.C., USA.

Hegney, D., H. Ross, P. Baker, C. Rogers-Clark, C. King, E. Buikstra, A. Watson-Luke, K. McLachlan, and L. Stallard. 2008. Identification of personal and community resilience that enhance psychological wellness: a Stanthorpe study. Centre for Rural and Remote Area Health, The University of Queensland and University of Southern Queensland, Toowoomba, Australia.

Henry, G. T. 1990. Practical sampling. Sage, Thousand Oaks, California, USA. http://dx.doi.org/https://doi.org/10.4135/9781412985451

House of Commons, Culture, Media and Sport Committee. 2008. Tourism. Eighth Report of Session 2007-08, Vol. 1. The Stationery Office, London, UK.

Karlsson, M., and G. K. Hovelsrud. 2015. Local collective action: adaptation to coastal erosion in the Monkey River Village, Belize. Global Environmental Change 32:96-107. http://dx.doi. org/10.1016/j.gloenvcha.2015.03.002

Kelly, C., A. Ferrara, G. A. Wilson, F. Ripullone, and A. Nole. 2015. Community resilience and land degradation in forest and shrubland socio-ecological systems: evidence from Gorgoglione, Basilicata, Italy. Land Use Policy 46:11-20. http://dx.doi. org/10.1016/j.landusepol.2015.01.026

Kelly, G., and K. Hosking. 2008. Nonpermanent residents, place attachment, and "sea change" communities. Environment and Behavior 40(4):575-594. http://dx.doi.org/10.1177/0013916507302246

Khanlou, N., and R. Wray. 2014. A whole community approach toward child and youth resilience promotion: a review of resilience literature. International Journal of Mental Health and Addiction 12:64-79. http://dx.doi.org/10.1007/s11469-013-9470-1

Lewicka, M. 2008. Place attachment, place identity, and place memory: restoring the forgotten city past. Journal of Environmental Psychology 28(3):209-231. http://dx.doi.org/10.1016/ j.jenvp.2008.02.001
Lewicka, M. 2011. Place attachment: how far have we come in the last 40 years? Journal of Environmental Psychology 31(3):207230. http://dx.doi.org/https://doi.org/10.1016/j.jenvp.2010.10.001

Leykin, D., M. Lahad, O. Cohen, A. Goldberg, and L. Aharonson-Daniel. 2013. Conjoint community resiliency assessment measure-28/10 items (CCRAM28 and CCRAM10): a self-report tool for assessing community resilience. American Journal of Community Psychology 52:313-323.

MacDougall, C., and E. Fudge. 2001. Planning and recruiting the sample for focus groups and in-depth interviews. Qualitative Health Research 11(1):117-126. http://dx.doi.org/10.1177/10497$\underline{3201129118975}$

Maclean, K., M. Cuthill, and H. Ross. 2014. Six attributes of social resilience. Journal of Environmental Planning and Management 54(1):144-156. http://dx.doi.org/10.1080/0964056$\underline{8.2013 .763774}$

Maclean, K., H. Ross, M. Cuthill, and B. Witt. 2016. Converging disciplinary understandings of social aspects of resilience. Journal of Environmental Planning and Management 60(3):519-537. http://dx.doi.org/10.1080/09640568.2016.1162706

Magis, K. 2010. Community resilience: an indicator of social sustainability. Society and Natural Resources 23:401-416. http:// dx.doi.org/10.1080/08941920903305674

Majevadia, J. 2016. Where we live now. Productivity in Cornwall: a place-based approach. Briefing Note. May 2016. The British Academy, London, UK.

Marshall, N. A. 2007. Can policy perception influence social resilience to policy change? Fisheries Research 86:216-227. http:// dx.doi.org/https://doi.org/10.1016/j.fishres.2007.06.008

Marshall, N. A., S. E. Park, W. N. Adger, K. Brown, and S. M. Howden. 2012. Transformational capacity and the influence of place and identity. Environmental Research Letters 7(3):034022. http://dx.doi.org/10.1088/1748-9326/7/3/034022

Masten, A. S., and J. Obradovic. 2008. Disaster preparation and recovery: lessons from research on resilience in human development. Ecology and Society 13(1): 9. http://dx.doi. org/10.5751/ES-02282-130109

Matin, N., and R. Taylor 2015. Emergence of human resilience in coastal ecosystems under environmental change. Ecology and Society 20(2): 43. http://dx.doi.org/10.5751/ES-07321-200243

Miles, M. B., and A. M. Huberman. 1994. Qualitative data analysis: an expanded sourcebook. Second edition. Sage, Thousand Oaks, California, USA.

Morgan, D. L. 1996. Focus groups. Annual Review of Sociology22:129-152. http://dx.doi.org/https://doi.org/10.1146/ annurev.soc.22.1.129

Morgan, D. L., and R. A. Krueger 1993. When to use focus groups and why. Pages 3-19 in D. L. Morgan, editor. Successful focus groups: advancing the state of the art. Sage, Thousand Oaks, California, USA. http://dx.doi.org/10.4135/9781483349008.n1

Newman, L., and A. Dale. 2005. Network structure, diversity, and proactive resilience building: a response to Tompkins and Adger. Ecology and Society 10(1): r2. http://dx.doi.org/10.5751/ ES-01396-1001r02 
Norris, F. H., and S. A. Murrell. 1988. Prior experience as a moderator of disaster impact on anxiety symptoms in older adults. American Journal of Community Psychology 16(5):665683. http://dx.doi.org/10.1007/BF00930020

Norris, F. H., S. P. Stevens, B. Pfefferbaum, K. F. Wyche, and R. L. Pfefferbaum. 2008. Community resilience as a metaphor, theory, set of capabilities, and strategy for disaster readiness. American Journal of Community Psychology 41:127-150. http:// dx.doi.org/10.1007/s10464-007-9156-6

Oxford Consultants for Social Inclusion (OCSI). 2009a. Rural deprivation in Cornwall and the Isles of Scilly: profile report for Boscastle. Final report, OCSI, Brighton, UK.

Oxford Consultants for Social Inclusion (OCSI). 2009b. Rural deprivation in Cornwall and the Isles of Scilly: profile report for Wadebridge. Final report, OCSI, Brighton, UK.

Pfefferbaum, R. L., B. Pfefferbaum, and R. L. van Horn. 2011. Communities advancing resilience toolkit (CART): the CART integrated system. Terrorism and Disaster Center at the University of Oklahoma Health Sciences Center,Oklahoma City, Oklahoma, USA.

Quinlan, A. E., M. Berbes-Blazquez, H. L. Jamila, and G. D. Peterson. 2015. Measuring and assessing resilience: broadening understanding through multiple disciplinary perspectives. Journal of Applied Ecology 53(3):677-687. http://dx.doi.org/10.1111/13$\underline{65-2664.12550}$

Rey-Valette, H., B. Rulleau, A. P. Hellequin, C. Meur-Férec, and H. Flanquart. 2015. Second-home owners and sea-level rise: the case of the Languedoc-Roussillon region (France). Journal of Policy Research in Tourism, Leisure and Events 7(1):32-47. http:// dx.doi.org/10.1080/19407963.2014.942734

Ross, H., and F. Berkes. 2014. Research approaches for understanding, enhancing, and monitoring community resilience. Society and Natural Resources 27(8):787-804. http://dx.doi. org/10.1080/08941920.2014.905668

Ross, H., M. Cuthill, K. Maclean, D. Jansen, and B. Witt. 2010. Understanding, enhancing and managing for social resilience at the regional scale: opportunities in North Queensland. Reef and Rainforest Research Centre Ltd. Cairns, Australia. [online] URL: http:// www.rrrc.org.au/publications/social_resilience_northqueensland. $\underline{\mathrm{html}}$

Schoon I. 2006. Risk and resilience: adaptations in changing times. Cambridge University Press, Cambridge, UK. http://dx.doi. org/10.1017/CBO9780511490132

Solnit, R. 2009. A paradise built in hell. Penguin Books, New York, New York, USA.

Stedman, R. C. 2006. Understanding place attachment among second home owners. American Behavioral Scientist 50(2):187205. http://dx.doi.org/10.1177/0002764206290633

Strauss, A. 1987. Qualitative analysis for social scientists. Cambridge University Press, Cambridge, UK. http://dx.doi. org/10.1017/CBO9780511557842

Theodori, G. 2004. Community attachment, satisfaction, and action. Journal of the Community Development Society 35(2):7386. http://dx.doi.org/10.1080/15575330409490133
UK National Statistics. 2011. Population census 2011-03-27. [Online] URL: https://www.ons.gov.uk/peoplepopulationandcommunity/ populationandmigration/populationestimates/bulletins/2011censuspopulationestimatesfortheunitedkingdom/2012-12-17

Vaske, J. J., and K. C. Kobrin. 2001. Place attachment and environmentally responsible behavior. Journal of Environmental Education 32:16-21. http://dx.doi.org/10.1080/00958960109598658

Walker, B., and D. Salt. 2012. Resilience practice: building capacity to absorb disturbance and maintain function. Island Press, Washington, D.C., USA. http://dx.doi.org/10.5822/978-1-61091-231-0

Wilson, G. A. 2012. Community resilience and environmental transitions. Routledge, Oxford, UK.

Woolcock, M., and Narayan, D. 2000. Social capital: implications for development theory, research, and policy. World Bank Research Observer 15(2):25-49. http://dx.doi.org/10.1093/ wbro/15.2.225 